Z tajnych archiwów radzieckich (6)

MICHA£ GNATOWSKI (Białystok)

\title{
RADZIECKIE DOKUMENTY O STARANIACH ZSRR W CELU PONOWNEGO ZAJECCIA ZIEM REGIONU BIAŁOSTOCKIEGO
}

\section{Wstęp}

W czasie kwerend w poradzieckich archiwach na Białorusi znalazłem dokumenty świadczące o tym, że ZSRR nie zrezygnował ze wschodnich ziem polskich, zagarniętych w $1939 \mathrm{r}$. w wyniku agresji dokonanej w zmowie $\mathrm{z}$ hitlerowskimi Niemcami. Nie zrezygnowano też z Białostocczyzny, pomimo że nie występował na tych terenach tak ostro czynnik narodowościowy, stanowiący - jak twierdziła oficjalna propaganda - uzasadnienie zajęcia tych ziem w celu wyzwolenia narodowego Białorusinów i Ukraińców. Publikowane dokumenty świadczą, że ZSRR robił wszystko, by przywrócić utraconą po najeździe Niemiec na ZSRR kontrolę nad tymi terenami. Ogólne problemy z tym związane autor przedstawił szerzej w książce Białostockie Zgrupowanie Partyzanckie ${ }^{1}$ oraz $\mathrm{w}$ artykule Kulisy radzieckich staran o ponowne wtaczenie regionu biatostockiego w sktad ZSRR (1942-1944), opublikowanego w niniejszym tomie "Studiów...".

Region białostocki traktowany był przez radzieckie władze jako radziecki teren, wysunięty najdalej na zachód i wymagający szczególnej troski. $\mathrm{Na}$ tym bowiem terenie radzieckie podziemie miało wręcz znikome wpływy, podczas gdy polskie podziemie miało rozbudowane struktury i cieszyło się poparciem miejscowej ludności. Podejmowano więc różne działania, by ten stan zmienić na swoją korzyść. Publikowane dokumenty przedstawiają ra-

1 Białostockie Zgrupowanie Partyzanckie, Białystok 1994. 
dzieckie wysiłki programowo-organizacyjne, zmierzające do ponownego opanowania i sowietyzacji regionu białostockiego.

Dokumenty publikujemy w układzie chronologicznym: pierwszy jest z kwietnia 1943 r. a ostatni z maja 1944 r. Sa to dokumenty wytworzone przez aparat KC KP(b)B i BSzRP oraz białostockie komitety obwodowe. Wszystkie dokumenty publikowane są po raz pierwszy w całości, w języku oryginału, tj. w języku rosyjskim. Pochodzą one ze zbiorów Narodowego Archiwum Republiki Białoruskiej (NARB) w Mińsku, z zespołów KC KP(b)B i BSzRP.

W dokumentach występują następujące, mniej znane, skróty:

БШПД - Белорусский Ш таб Партизанского .Движения

ВКП(б) - Всесоюзная Коммунистическая Партия (большевиков)

КП(б)Б - Коммунистическая Партия (большевиков) Белоруссии

к-р - коман.дир

ЛКСМБ - Ленинский Коммунистический Союз Молодежи Белоруссии

м. - местечко

межкрайком - межрайонный комитет

обком - областной комитет

орггруппа - организационная группа

пом. $\quad-$ помощник

пред. - - председатель

райком - районный комитет

с-3 - северо-западнее

ст. пом. - старший помошник

т., тов: тт. -- товарищ, товарищи

зам. - заместитель

зав. - заведуюший

ж.д. - жкелезная дорога 


\section{Dokument 1}

(1943 kwiecien), Moskwa, - Informacja KC KP(b)B o przygotowanych kadrach dla obwodu biatostockiego $i$ wilejskiego.

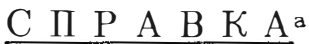

\section{О МЕРОПРИЯТИЯХ ПО КАДРАМ Д.Л БЕЛОСТОКСКОЙ И ВИЛЕЙСКОЙ ОБЛАСТЕЙ.}

Белостокская областная партийная организация до начала Отечественной войны насчитывала 5630 членов и кандидатов партии. В нагалле войны из области эвакуировалюсь в глубь страны 1410 членов и кандидатов ВКП(б), остальные коммунисты частью ушли в ряды Красной Армии и частью остались на территории оккупированных областей Белоруссии, в том числе и на территории Белостокской области.

Руководяцие работники Белостокской области в настоящее время распределяются следуюшим образом:

\begin{tabular}{|c|c|c|c|c|c|c|c|c|}
\hline $\begin{array}{c}\text { Наименование } \\
\text { должности }\end{array}$ & Всего & $\begin{array}{c}\text { В Крас- } \\
\text { ной } \\
\text { Армии }\end{array}$ & $\begin{array}{c}\text { На под- } \\
\text { поль- } \\
\text { ной } \\
\text { работе }\end{array}$ & \begin{tabular}{|c|} 
Раб. по \\
партиз. \\
движе- \\
ниюо
\end{tabular} & $\begin{array}{l}\text { В обкоме } \\
\text { КП(б)Б }\end{array}$ & $\begin{array}{c}\text { Работ. } \\
\text { в вост. } \\
\text { облас- } \\
\text { тях }\end{array}$ & $\begin{array}{l}\text { ІІоги- } \\
\text { бло }\end{array}$ & $\begin{array}{r}\text { Нет } \\
\text { сведе- } \\
\text { ний }\end{array}$ \\
\hline $\begin{array}{l}\text { Секретари обкома } \\
К П(б) Б\end{array}$ & 7 & 1 & 1 & 1 & 2 & 1 & - & 1 \\
\hline $\begin{array}{l}\text { Зав. отделами } \\
\text { обкома } K \Pi(б) Б\end{array}$ & 10 & 4 & - & - & - & 2 & - & 4 \\
\hline $\begin{array}{l}\text { Секретари горкомов } \\
\text { КП(б)Б }\end{array}$ & 10 & 6 & - & 1 & 1 & 2 & - & - \\
\hline $\begin{array}{l}\text { Секретари райкомов } \\
\text { КП(б)Б }\end{array}$ & 78 & 27 & 6 & 7 & 4 & 7 & 6 & 21 \\
\hline $\begin{array}{l}\text { ІІред. облисполкома } \\
\text { и его заместители }\end{array}$ & 3 & 1 & - & - & - & 1 & 1 & - \\
\hline $\begin{array}{l}\text { Зав. отделами } \\
\text { Облисполкома }\end{array}$ & 6 & 1 & - & - & - & 2 & - & 3 \\
\hline $\begin{array}{l}\text { Председатели } \\
\text { райисполкомов }\end{array}$ & 26 & 4 & 2 & - & 1 & 4 & - & 15 \\
\hline
\end{tabular}


Указанные в сводке работники, находящиеся на подпольной партийной работе и в партизанских отрядах, действуют в основном не на территории Белостокской области.

Значительная часть коммунистов и беспартийного советского актива, оставпииеся на территории Белостокской области, а также многие из руково,дяцих работников, местонахож.дение которых пока не установлено, безусловно действуют в партизанских отрядах, диверсионных группах и подіольных партийных организациях в районах Белостокской области, но св.язи с этими товарищами пока еще не установлены.

По именщимся данным, на северо-западе области, в районе Августовских лесов, действуют болыпие партизанские отряды, насчитывающие свыпе 3000 чел. Кроме того, в районе м-ка Супрасль Белостокского района, действуют два неболыних партизанских отр.яда, один из которых возглавляется т. Гаевым (в проплом милиционер г. Белостока).

В последнее время ЦК и обкомом КП(б)Б принят ряд мер по установлению связи с действуюгцими в области отрядами и группами и по дальнейпгему развертыванию подпольной работы и партизанского движения. В Белостокскую область направлены заместитель уполномоченного ШК КП(б)Б по области т. Сукачев, член обкома КП(б)Б - секретарь обкома ЛКСМБ т. Стрижак и спец.отря.д т. Войцеховского.

ЦК и обкомы КП(б)Б подготовлены для отправки в область уполномоченные ПК и обкома КП(б)Б по группам районов: т. Бастун в Гродненскую группу районов, т. т. Шурман и Сидорович - в Снядовскую группу районов, т. Карабань - в Брянскую группу, т. Кундович - в Ла́пскую группу районов, т. Сокольчик - в Ломжинскую группу районов и т. Овсейчик - в Скидельскую группу районов, которые будут направлены в свои группы районов с партизанскими отря,дами, перебазирующциис.я из восточных областей Белоруссии.

Для отправки в Белостокскую область также подготовлены отря,цы и группы: т. Морщинина - в Августовский район, т. Степанова - в Свислочский и Крынковский районы, т. Исаенко - в Гродненский район, т. Гордиенко - в Августовский район, т. Казакова в Белостокский район, т. Стомы - в Брянский район, т. Шломанова - в Волковысский район.

Основным недостатком в работе по установлению связей с действуюцими в области отрядами и группами и по дальнейнему ра- 
звертыванию подпольной работы и партизанского двизения является отсутствие руководяцего подпольного партийного центра в области.

ВИЛЕЙСКАЯ областная партийная организация к началу Отечественной войны насчитывала 2577 членов и кандидатов ВКП(б). В начале войны в глубь страны из Вилейской области эвакуировалось 730 членов и кандидатов партии, остальные коммунисты частью ушли в ряды Красной армии и частью остались на территории оккупированных областей Блеоруссии, в том числе и на территории Вилейской области.

На территории Вилейской области действует ряд партизанских бригад и отрядов, которые провели большую работу по разгрому гарнизонов и разрушению коммуникаций противника.

За последние 4-5 месяцев в партизанском движении Вилейской области произошли изменения. В осенне-зимний период 1942-43 г. ряд партизанских отрядов, ведя бои с крупными силами карателей и регулярных частей немецкой армии, вынуждены были оставить районы своей деятельности и отойти к границам Минской и Витебской областей.

В декабре 1942 г. ЦК и обкомом КП(б)Б на подпольную работу в Вилейскую область была направлена болыная группа работников. Межрайонными уполномоченными были направлены: т. Соврей - секретарь Миорского РК КП(б)Б, т. Гончаренко - начальник Вилейского Облзо, т. Тубелис - инструктор обкома КП(б)Б и др. В результате боев с немецкими оккупантами т. Гончаренко погиб, т. Соврей - серьезно ранен, а т. Тубеликс вынужден был перейти линиғо фронта и вернуться в распоряжение обкома КП(б)Б. В области остались: редактор областной газеты т. Василевский и уполномоченный ПК ЛКСМБ т. Ольшанский с группой комсомольских работников.

Руководяцие работники Вилейской области в настоящее время распределяяотся следуюшим образом: 


\begin{tabular}{|c|c|c|c|c|c|c|c|c|}
\hline $\begin{array}{c}\text { Наименование } \\
\text { должности }\end{array}$ & Всего & $\begin{array}{c}\text { В Крас- } \\
\text { ной } \\
\text { Армии }\end{array}$ & $\begin{array}{c}\text { На под- } \\
\text { поль- } \\
\text { ной } \\
\text { работе }\end{array}$ & $\begin{array}{c}\text { Раб. по } \\
\text { партиз. } \\
\text { движе- } \\
\text { ниюо }\end{array}$ & $\begin{array}{l}\text { В обкоме } \\
\text { КП(б)Б }\end{array}$ & $\begin{array}{c}\text { Работ. } \\
\text { в вост. } \\
\text { облас- } \\
\text { тях }\end{array}$ & $\begin{array}{l}\text { Поги- } \\
\text { бло }\end{array}$ & $\begin{array}{c}\text { Нет } \\
\text { сведе- } \\
\text { ний }\end{array}$ \\
\hline $\begin{array}{l}\text { Секретари обкома } \\
\text { КП(б)Б }\end{array}$ & 7 & 5 & - & - & 1 & - & 1 & - \\
\hline $\begin{array}{l}\text { Зав. отделами } \\
\text { обкома КП(б)Б }\end{array}$ & 10 & 3 & - & - & - & - & 1 & 6 \\
\hline $\begin{array}{l}\text { Секретари горкомов } \\
\text { КП(б)Б }\end{array}$ & 4 & 3 & - & - & 1 & - & - & - \\
\hline $\begin{array}{l}\text { Секретари райкомов } \\
\text { КП(б)Б }\end{array}$ & 60 & 27 & 10 & - & 2 & 5 & 7 & 9 \\
\hline $\begin{array}{l}\text { Пред. облисполкома } \\
\text { и его заместители }\end{array}$ & 4 & 2 & 1 & - & 1 & - & - & - \\
\hline $\begin{array}{l}\text { Зав. отделами } \\
\text { Облисполкома }\end{array}$ & 6 & 2 & 1 & - & - & - & - & 3 \\
\hline $\begin{array}{l}\text { Председатели } \\
\text { райисполкомов }\end{array}$ & 20 & 2 & 5 & - & 3 & 2 & 4 & 4 \\
\hline
\end{tabular}

Указанные в сводке работники, находящиеся на подпольной партийной работе и в партизанских отрядах, действуюо в основном не на территории Вилейской области.

IК и обкомом КШ(б)Б по,дготовлены для отправки в Вилейскую область следуюоцие т. т.: Монахов - секретарь Шоставского РК КП(б)Ю, Титовец - председатель Вилейского горсовета, Шевченко - председатель Шарковпциского райисполкома, Булко-Чиж - редакционный работник, Шиманович - работник обкома ЛКСМБ и т. т. Булайчик, Евмененко и Долгий, которые могут быть использованы организаторами поділольнй партийной работы и партизанского движения в районах.

Основным недостатком в руководстве подпольной партийной работой и партизанским движением в Вилейской области, как и в Белостокской области, является отсутствие руково,цяпего по,дпольного центра на территории области.

Для улучпения работы по руководству подпольными партийными организациями и партизанским движением в Белостокской и Вилейской областях считаем необходимым:

1. Ускорить засылку в в Вилейскуюо область: т. Монахова секретаря Поставского РК КП(б)Б, т. Титовец - пре,дседателя Вилейского горсовета и т. Шевченко - председателя Шарковпциского райисполкома. 
2. Ускорить переброску в Белостокскую и Вилейскую области уполномоченных ШК и обкомов КП(б)Б по районам, а такљке подготовленные организаторские группы партизанского движения.

3. Перебросить в Вилейскую область с группой работников, имеюгцх опыт партизанской борьбы, т. ЖУКОВИЧА - секретаря Куренецкого РК КП(б)Б - из Борисовского района, Минской области.

4. Отозвать из рядов Красной Армии длля направления в Белюстокскую область:

т. Сергеева - секретаря обкома КП(б)Б по транспорту.

т. Грибоедова - зам. председателя Облисполкома.

т. Милова - секретаря Белостокского горкома КП(б)Б.

т. Ковалева - секретаря Гродненского райкома КП(б)Б.

т. Ротайко - председателя Гродненского горсовета.

т. Кавецкого - секретаря Августовского РК КП(б)Б.

т. Балашкевича - секретаря Августовского РК КП(б)Б.

5. Отозвать из восточных областей СССР:
т. Корпаченко - заведуюпего транспортным отделом обкома КП(б)Б.
т. Сысоева - секретаря Советского РК КП(б)Б г. Белостока.
т. Гудеева - председателя Советского райисполкома г. Белостока.

6. Отозвать из рядцов Красной Армии для направления в Вилейскую область:

$\begin{array}{ll}\text { т. Краскова } & - \text { председателя Вилейского Облисполкома. } \\ \text { т. Јагуна } & - \text { секретаря обкома КШ(б)Б. } \\ \text { т. Аксенова } & - \text { заместителя председателя Облисполкома. }\end{array}$

7. Поручить Белостокскому и Вилейскому обкомам КП(б)Б подобрать группу работников из бывпих членов КПЗБ и др. местных работников, владеюоцими польским и литовским языками, для направления их в Белостокскую и Вилейскую области.

\section{СЕКРЕТАРЬ ШК КП(б) БЕЈОРУССИИ ПО КАДРАМ (podpis) (АВХИМОВИЧ)}

гाт-10.

Na górze dokument z prawej strony napis kancelaryjny: „do p. 3 op”, tj. do punktu 3 , teczka specjalna. 
Oryginał, maszynopis.

Źródło: NARB w Mińsku, zesp. 4, spr. 3, t. 1243, k. 91-96.

a Wielkie litery oryginału.

b Skreślone słowa: „do tych obwodów kierownictwa podziemnych komitetów obwodowych KP(b)B a zwłaszcza do obwodu białostockiego t. Krawczenkę - sekretarza obkomu KP(b)B i t. Samutina - członka obkomu, redaktora gazety obwodowej."

\section{Dokument 2}

1943 czerwiec 12, Moskwa, - Uchwata KC KP(b)B w sprawie Biatostockiego Komitetu Obwodowego KP(b)B.

$\underline{\text { особая папка }}^{\text {a }}$ Iролетарыі ўсіх краін, еднаііцеся!

Іәнтральны Камітэт

Комуністычнай Партыі (большэвікоў) Беларусі

№ $169^{\mathrm{b}}$

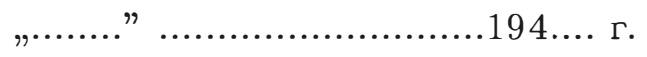

IIOСТАНОВЛЕНИЕ

ПК КП(б) БЕЛОРУССИИ от „12”с июня 1943 го,ца

ВОIІРОСЫ БЕЛОСТОКСКОГО ОБКОМА КП(б)Б.

1. В целях дальнейшего расширения партизанской борьбы на территории Белостокской области, организационного укрепления движения, усиления партийной и политической работы среди населения, а также для организации борьбы с ведущейся националистической обработкой населения со стороны различного рода польских нелгегальных организаций, - направить в качестве уполномоченных ШК КП(б)Б по районам Белостокской области сле,цующих товарищей:

БАСТУНА Павла Романовича - гоо Гродненскому району, IIIУ РМАНА Ивана Семеновича - по Сня,довскому району, КАРАБАНЬ Николая Јеонтьевича - по Брянскому району, 
КУНДОВИЧА Виталия Викентьевича - по Лапскому району,

СОКО ІЬ ЧИКА Александра Филиппювича - по Ломжинскому району,

АВСЕИЧИКОВАе Илью Михайловича - по Скидельскому району.

2. Поручить Белорусскому пाтабу партизанского движения:

а) Организовать переброску самолетами т. т. Шурмана, Coкольчика, Авсенчикова, Бастуна - в районы Ивенецкой пущи Барановичской области, к уполномоченному ПК КП(б)Б по Барановичской области т. Черныпову.

т. т. Кундовича и Карабань - в район действия партизанских отря,дов секретаря Минского обкома КП(б)Б т. Варвапеня;

б) сформировать отря,ды по 50 чел. Из числа партизанских отрядов, действуюших под руководством т. т. Черныпова и Варвапеня, знающих районы Белостокской области, и направить их в районы Белостоксктй области с уполномоченным ПК КП(б)Б;

в) выделить в распоряжение уполномоченных ПК КП(б)Б по районам по 2 рации РПО с радистами.

3. Отозвать из рядов Красной Армии для использования на руководящей партийной по,дпольной работе в Белостокской области сле,дуюгцих товарищей:

Сергеева Андрея Сергеевича - секретаря Белостокского обкома КП(б)Б по транспорту.

Грибоедова Николая Ивановича - зам. Председателя Белостокского облисполкома.

Милова Семена Петровича - секретаря Белостокского райкома КП(б)Б.

Ковалева Алексан,дра Андреевича - секретаря Гро,дненского райкома КП(б)Б.

Ратайко Петра Ивановича - председателя Гро,дненского горсовета.

Балапневича Филиппа Ефимовича - секретаря Августовского РК КП(б)Б.

Ковецкого Андрея Никитича - секретаря Августовского РК КП(Б)Б.

4. Просить ШК ВКП(б) отозвать в распоряжение ШК КП(б)Б для использования на подпольной партийной работе в Белостокской области сле,дующих товарищей:

Корпаченко Василия Пантелевича - зав. Транспортным отде- 
лом Белостокского обкома КП(б)Б, ныне работающего в г. Омске зам.нач. управления железной дороги.

Сысоева Павла Тимофеевича - секретаря Советского РК КП(б)Б г. Белостока, ныне работающего в Ставропольском районе Куйбышевской области.

Гудеева Сергея Борисовича - председателя Советского райисполкома г. Белостока, ныне работающего зав.райторготделом в Лунинском районе Пензенской области.

5. Поручить Белостокскому обкому КП(б)Б по,добрать группу работников из бывших членов КПЗБ и других местных работников владеющих польским языком, для направления по специальным заданиям в Белостокскую область.

\section{A: (Sześć nieczytelnych podpisów)}

ПРОТИВ:

Źródło: NARB w Mińsku, zesp. 4, spr. 3, t. 1243, k. 66 (dwustronna)

a Słowa „teczka specjalna” wpisane i podkreślone odręcznie.

b $\mathrm{Nr}$ wpisany odręcznie.

c Dzień wpisany odręcznie.

d Wielkie litery i podkreślenie oryginału.

e Pomyłka powinno być Owsiejczyk.

\section{Dokument 3}

1943 czerwiec 20, Moskwa, Informacja BSzRP o stanie radzieckiego podziemia $w$ obwodzie biatostockim $i$ przedsięwzięciach $w$ celu jego rozbudowy.

Сов. секретно $^{\mathrm{a}}$

По имеющимся в Б.Ш.П.Д. не личным данным по состоянию на 20.6.43 г. на территории Белостокской области действует до 3,5 тысяч партизан, дислоцирующихся в районе Августовский лесов. Связи с отрядами Б.Ш.П.Д. не имеет и результаты боевых действий не известны ${ }^{1}$.

Отсутствие связи, а значит и отсутствие учета боевых действий партизан объясняется дальностью области от линии фронта и не 
имением на территории лиц и групп, засланных по спецзаданиям.

Дляя осуществления руководства партизанским движением и дальнейшего его развития, для организации подпольной партийной работы в области направлены:

а) Пом. уполномоченного IIК КП(б)Б и пाтаба по области тов. Сукачев,

б) Пом. уполномоченного IK KI(б)Б и штата по области тов. Стрижак,

в) Партизанский отряд тов. Войцеховского, в Белостокский и Крынковский районы,

г) Партизанский отряд т. Степанова, в Волковысский район, при чем в распоряљкение этих ,двух отрядов передан партизанский отря,д „Ленинского Комсомола" численностью в 150 челювек.

Партизанские отряды Войцеховского и Степанова и тов. Сукачев на 20.6.43 г. находились в Јипечанской пуще, что в 65 клм. северо-западнее Барановичи. Тов. Стрижак в первых числах июля направился к цели из отряда Сикорского ${ }^{2}$ (последний дислоцируется в Березовском районе, Брестской области).

д) Группа во главе с уполномоченным IK KШ(б)Б и пाтаба тов. Исаенком, в Сопоцкинский район,

е) Группа во главе с уполномоченным тов. Гордиенко, в Граевский район,

ж) Орггруппа во главе с уполномоченным тов. Козаковым, в Соколковский район.

Эти группы в движении к цели и на 20.6.43 г. находились в 9 клм. северо-восточнее м. Борковичи.

Готовы и ожидают отправки с аэро,дрома Москва 9 групп во главе с уполномоченными IКК КП(б)Б и пाтаба:

а) группа тов. Шурмана, в Сня,довский район,

б) " " Овсейчика, в Сидельский район,

в) " " Сокольчика, в Јомжинский район,

г) " " Кундовича, в Јапский район,

д) " " Карабань, в Бранский район,

е) " " Бастун, в Гродненский район,

эк) " " Шлгаманова, в Свислочский район,

3) " " Стома, в Чижевский район,

и) " " " Трацевского, в Августовский район.

Также готовы и ожидают отправки с аэродромов Москвы: ко- 
ман,дование партизанского отряда Дьякова (последнему разрешено взять 50 чел. с вооружением из брига,ды Матевосяна ${ }^{3}$. Район действия Бельский Район) и группа Самутина ${ }^{4}$,для организации подпольной партийной печати в области.

Все отряды, группы и лица снабжены рациями РПО и радистами, а также двумя типографиями.

Rękopis, niepodpisany.

Źródło: NARB w Mińsku, zesp. 3500, spr. 2, t. 1024, k. 7-8.

a Podkreślenie oryginału.

${ }^{1}$ Informacja o 3,5 tys. partyzantów w Puszczy Augustowskiej w połowie 1943 r. nie znajduje potwierdzenia w innych dokumentach. W tym czasie w puszczy były tylko pojedyncze grupy i oddziały AK. Partyzantki radzieckiej nie było w ogóle.

2 Siergiej Sikorskij w kwietniu 1943 r. skierowany został do obwodu brzeskiego, początkowo jako pełnomocnik KC KP(b)B i BSzRP, następnie Brzeskiego Podziemnego Komitetu Obwodowego KP(b)B.

${ }^{3}$ Chaczyk Matewosjan był dowódca Brygady im. Czapajewa, którą w sierpniu $1943 \mathrm{r}$. skierowano z obwodu mińskiego do dyspozycji Białostockiego Zgrupowania Partyzanckiego.

4 Wasilij Samutin przewidziany był początkowo na redaktora gazety obwodowej. 27.VII. 1943 r. KC KP(b)B powołał go na I sekretarza Białostockiego Podziemnego Komitetu Obwodowego KP(b)B. Redaktorem gazety „Biełostokskaja Prawda” został Stiepan Majjchrowicz.

\title{
Dokument 4
}

1943 lipiec 8, Moskwa, - Uchwata Komitetu Obwodowego KP(b)B w Biatymstoku w sprawie nazwy gazety obwodowej.

\author{
ПРОТОКО J № 5 \\ ЗАСЕДАНИЯ БЕЈОСТОКСКОГО ОБКОМА \\ КП(б) БЕЈОРУССИИ
}

От 8 июля 1943 года

ПРИСУТСТВУЮТ: т. т. Эльман, Кильбин и Самутин.

1. СЈУША ЛИ: О названии областной газеты.

ПОСТАНОВИЛИ: В связи с тем, что областная газета будет выходить на русском языке, просить ШК КП(б)Б утвердить название 
областной газеты Белостокского Обкома КІІ(б)Б - „Белостокская Прав,да” вместо - „Вольная праца”.

\section{СЕКРЕТАРЬ БЕЛОСТОКСКОГО \\ ОБКОМА КІІ(б)Б (podpis) (ЭЈIЬMAH)}

Oryginał, maszynopis.

Źródło: NARB w Mińsku, zesp. 4, spr. 3, t. 1243, k. 46.

a Wielkie litery oryginału.

b Obok podpisu sekretarza okragła pieczęć komitetu. W obwódce pieczęci od góry napis: „Białostocki Komitet Obwodowy KP(b) Białorusi” w języku białoruskim i niżej to samo w języku rosyjskim. W środku pieczęci liczba „041”.

\section{Dokument 5}

1943 lipiec 13, Moskwa, - Uchwata KC KP(b)B powotujqca kolegium redakcyjne antyfaszystowskiej mtodzieżowej gazety "Motodoj Partizan".

Пролетарыі ўсіх краін, еднаііцеся!

ІІЭНТРАЛЬНЫ КАМІТЭТ

КОМУНІСТЬЧЧНАЙ IIAРТЫІ (большэвікоў) БЕЛАРУСI

№ $172^{\mathrm{a}}$

n..........

.194 г.

IІОСТАНОВЛЕНИЕ

IIК КІ(б)БЕЛОРУССИИ от „13” ИЮЈЯ 1943 г. ${ }^{\text {b }}$

СЈИУІАЛИ:

О составе редакционной коллегии антифапистской молодежной газеты Белостокской области Белорусской ССР - „Молю,дой партизан".

\section{ІІОСТАНОВИЛИ:}

1. Утвер.дить редакционную коллегию антифапистской молюдежной газеты Белостокской области Белорусской ССР „Молодой партизан" в следуюшем составе: 


\section{ІІРИТЫІКОГО Сергея Осиповича, КАЧАНА Якова Иосифовича.}

2. Редактором газеты „Молодой партизан” утвердить тов. КАЧАНА Якова Иосифовича, кандидат в члены В КІІ(б), кандидатская карточка № 2142569 .

3A: (7 podpisów członków

IІРОТИв:

Biura KC KP(b)B,

w tym P. Ponomarenki)

Oryginał, maszynopis.

Źródło: NARB w Mińsku, zesp. 4, spr. 3, t. 1243, k. 202.

a Numer i data wpisane odręcznie.

b Wielkie litery i podkreślenia oryginału.

\section{Dokument 6}

1943 (po 24 sierpnia), Moskwa, - Wykaz partyjnych grup organizatorskich skierowanych do obwodu biatostockiego.

\section{II И $\mathrm{C} \mathrm{O} \mathrm{K}{ }^{\mathrm{a}}$}

направленных групп в Белостокскую область

\begin{tabular}{|c|c|c|c|}
\hline Пп & $\begin{array}{c}\Phi \text { амилия, имя } \\
\text { и отчество }\end{array}$ & $\begin{array}{c}\text { В качестве } \\
\text { кого направлен }\end{array}$ & $\begin{array}{l}\text { Когда } \\
\text { выбыл }\end{array}$ \\
\hline \multicolumn{4}{|c|}{ I. Грушша тов. Бастуна - Гродненский р-н } \\
\hline $\begin{array}{l}1 . \\
2 . \\
3 . \\
4 . \\
5 . \\
6 .\end{array}$ & $\begin{array}{l}\text { БАСТУН Павел Романович } \\
\text { БАБИЧ Василий Федорович } \\
\text { ЦИПЛАКОВ Антонина В. } \\
\text { СУСОВА Ф.И. } \\
\text { РОДИНА С.С } \\
\text { ШАФРОНСКИЙ Јеонид Я. } \\
\text { НЕРО.Д Јеонид Яковлевич }\end{array}$ & $\begin{array}{l}\text { Уполномоч.ШК КП(б) Б } \\
\text { Опер. работник } \\
\text { КСМ работник } \\
\text { Ра,цист } \\
\text { Ра,Дист } \\
\text { Наборщик } \\
\text { Начальник штаба }\end{array}$ & $23.8 .43 \mathrm{r}$. \\
\hline
\end{tabular}




\begin{tabular}{|c|c|c|c|}
\hline ІІп & $\begin{array}{c}\Phi \text { амилия, имя } \\
\text { и отчество }\end{array}$ & $\begin{array}{l}\text { В качестве кого } \\
\text { направлен }\end{array}$ & $\begin{array}{l}\text { Ког,да } \\
\text { выбыл }\end{array}$ \\
\hline \multicolumn{4}{|c|}{ II. Группа т. Овсейчик - Скидельскиий район } \\
\hline $\begin{array}{l}1 . \\
2 . \\
3 . \\
4 . \\
5 .\end{array}$ & $\begin{array}{l}\text { ШУМСКАЯ Л.И. } \\
\text { МЕДВЕДЕВА Т.Н. }\end{array}$ & $\begin{array}{l}\text { Уполномоченный ЦLК КІІ(б)Б } \\
\text { радист } \\
\text { радист } \\
\text { КСМ работник } \\
\text { ІІечатник }\end{array}$ & \\
\hline \multicolumn{4}{|c|}{ III. Группа тов. Карабан - Брннский р-н } \\
\hline $\begin{array}{l}1 . \\
2 . \\
3 . \\
4 . \\
5 .\end{array}$ & $\begin{array}{l}\text { КАРАБАНЬ Н.Л. } \\
\text { КОЗЛЯКОВСКИЙ В.Г. } \\
\text { СТРОЕВ Е.С. } \\
\text { Баукова М.С. } \\
\text { ІІальчевский Н.В. }\end{array}$ & $\begin{array}{l}\text { Уполном. ШК КІІ(б)Б } \\
\text { Ра,дист } \\
\text { Радист } \\
\text { ІІечатник } \\
\text { ІІодрывник }\end{array}$ & \\
\hline \multicolumn{4}{|c|}{ IV. Группа т. Кундовича - Јапский р-н } \\
\hline $\begin{array}{l}1 . \\
2 . \\
3 . \\
4 . \\
5 .\end{array}$ & $\begin{array}{l}\text { Кун.цович В.В. } \\
\text { Сотова М.А. } \\
\text { Одинец Т.Ф. }\end{array}$ & $\begin{array}{l}\text { Уполном. ШК КІІ(б)Б } \\
\text { Ра,дист } \\
\text { Радист } \\
\text { КСМ работник } \\
\text { Опер. работник }\end{array}$ & 23.8 .43 г. \\
\hline \multicolumn{4}{|c|}{ V. Группа тов. Шурмана - Сня,довский р-н } \\
\hline $\begin{array}{l}1 . \\
2 . \\
3 . \\
4 . \\
4 . \\
5 .\end{array}$ & $\begin{array}{l}\text { IІІурман И.С. } \\
\text { Сидорович И.Е. } \\
\text { Брускин А.С. } \\
\text { Бурак М.З. } \\
\text { Тетерин М.И. } \\
\text { Воронов Н.М. }\end{array}$ & $\begin{array}{l}\text { Уполн. IК КІІ(б)Б } \\
\text { Радист } \\
\text { Радист } \\
\text { ІІечатник }\end{array}$ & 24.8 .43 г. \\
\hline \multicolumn{4}{|c|}{ VI. Группа т. Сокольчика - Сня,цовский р-н } \\
\hline $\begin{array}{l}1 . \\
2 . \\
3 . \\
4 . \\
5 .\end{array}$ & $\begin{array}{l}\text { Сокольчик А.Ф. } \\
\text { Нартып-Блук Е.В. } \\
\text { Буевич Е.К. } \\
\text { Киселев Т.А. } \\
\text { Сивко ІІ.ІІ. }\end{array}$ & 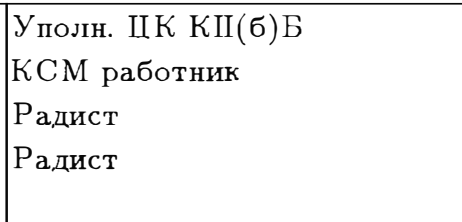 & \\
\hline
\end{tabular}




\begin{tabular}{|c|c|c|c|}
\hline III & $\begin{array}{c}\text { Фамилия, имя } \\
\text { и отчество }\end{array}$ & $\begin{array}{c}\text { В качестве кого } \\
\text { направлен }\end{array}$ & $\begin{array}{l}\text { Ког,да } \\
\text { выбыл }\end{array}$ \\
\hline \multicolumn{4}{|c|}{ VII. Группа тов. Дьякова - Соколковский р-н } \\
\hline $\begin{array}{l}1 . \\
2 . \\
3 . \\
4 .\end{array}$ & $\begin{array}{l}\text { Дьяков Р.А. } \\
\text { Забовников В.П. } \\
\text { Якунина К.А. } \\
\text { Ясюченя }\end{array}$ & $\begin{array}{l}\text { Уполн. IL КІІ(б)Б } \\
\text { Ра,цист } \\
\text { Раццист }\end{array}$ & 28.7 .43 г. \\
\hline \multicolumn{4}{|c|}{ VIII. Группа тов. Трацевского - Августовский р-н } \\
\hline $\begin{array}{l}1 . \\
2 . \\
3 . \\
4 . \\
5 . \\
6 . \\
7 .\end{array}$ & $\begin{array}{l}\text { Трацевский А.Д. } \\
\text { Толмачев С.И. } \\
\text { Рогозинский М.3. } \\
\text { Филимонов И.ІІ. } \\
\text { Губкин А.С. } \\
\text { Орлов В.Н. } \\
\text { Точилов В.Н. }\end{array}$ & Уполн. ШК КІІ(б)Б & 5.8 .43 г. \\
\hline \multicolumn{4}{|c|}{ 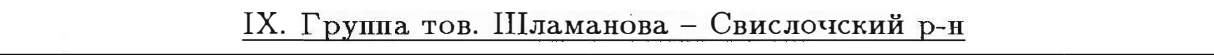 } \\
\hline $\begin{array}{l}1 . \\
2 . \\
3 . \\
4 . \\
5 . \\
6 . \\
7 . \\
8 .\end{array}$ & $\begin{array}{l}\text { ІІламанов А.Г. } \\
\text { Чычковский В.Д. } \\
\text { Трубчик Г.К. } \\
\text { Холудов Н.Г. } \\
\text { Колошева В.А. } \\
\text { Суконка И.К. } \\
\text { Меркулова С.С. } \\
\text { Багаева З.Г. }\end{array}$ & $\begin{array}{l}\text { Ра,цистка } \\
\text { Ра,дистка }\end{array}$ & 31.7 .43 г. \\
\hline \multicolumn{4}{|c|}{ Х. Груша тов. Стома - Ченевский ${ }^{\mathrm{b}} \mathrm{p}-\mathrm{H}$} \\
\hline $\begin{array}{l}1 . \\
2 . \\
3 . \\
4 . \\
5 . \\
6 . \\
7 .\end{array}$ & $\begin{array}{l}\text { Стома А.А. } \\
\text { Михальчѐко В.И. } \\
\text { Дубник И.А. } \\
\text { Дмитриев М.В. } \\
\text { Чальй И.А. } \\
\text { Дубовичцкий ІІ.Т. } \\
\text { Адамчик А.М. }\end{array}$ & & \\
\hline \multicolumn{4}{|c|}{ XI. Груща тов. Капуста - Гродненский р-н } \\
\hline $\begin{array}{l}1 . \\
2 . \\
3 . \\
4 . \\
5 .\end{array}$ & $\begin{array}{l}\text { Капуста } \Phi . \Phi . \\
\text { Синькович } \\
\text { Крайник } \Phi . I I . \\
\text { Колесников } \\
\text { Федотов }\end{array}$ & \begin{tabular}{|l} 
Комбриг \\
Нач. штаба \\
Іом. нач. штаба \\
Ра.дист \\
Ра.дист
\end{tabular} & 29.7 .43 г. \\
\hline
\end{tabular}




\begin{tabular}{|c|c|c|c|}
\hline Пп & $\begin{array}{c}\text { Фамилия, имя } \\
\text { и отчество }\end{array}$ & $\begin{array}{c}\text { В качестве кого } \\
\text { направлен }\end{array}$ & $\begin{array}{l}\text { Ког,да } \\
\text { выбылг }\end{array}$ \\
\hline \multicolumn{4}{|c|}{ XII. Группа тов. Самутина - Белостокская область } \\
\hline $\begin{array}{l}1 . \\
2 . \\
3 . \\
4 . \\
5 .\end{array}$ & $\begin{array}{l}\text { Самутин } \\
\text { Качан } \\
\text { Розенпптейн Д.И. } \\
\text { Жихневская Я.Ф. } \\
\text { Бонк }\end{array}$ & $\begin{array}{l}\text { Секретарь газеты } \\
\text { литработник } \\
\text { наборццица }\end{array}$ & $27.7 .43 \mathrm{r}$. \\
\hline
\end{tabular}

СТ. ПОМ. НАЧАЛЬНИКА ОПЕР. ОТДЕЛА ПО ДПОЛКОВНИК (podpis) (ШУТОВ)

IIIO- 2

Oryginał, maszynopis.

Źródło: NARB w Mińsku, zesp. 4, spr. 1, t. 7, k. 53-55.

a Wielkie litery i podkreślenia oryginału.

b Powinno być czyżewskim.

c Prawidłowo: Sienkiewicz (Iwan Afanasiewicz)

\section{Dokument 7}

1943 październik 14, Moskwa, - Wykaz oddziatów partyzanckich i grup organizatorskich obwodu białostockiego.

\section{О П И С А Н И $\mathrm{E}^{\mathrm{a}}$}

партизанских отрядов и групп Белостокской области

1. Отряд ВОЙПЕХОВСКОГО - командир т. Войцеховский Н.К., комиссар т. Андреев А.Е, в отряде 150 чел.; перебропен из Москвы в апреле 1943 года. Отряд должен действовать в районе г. Белостока.

2. Отряд имени КАЛИНИНА М.И., командир т. Степанов С.М., комиссар т. Лукьянов Г.С., в отря,де 165 чел., причем свыпе 100 
- местные люди. Основное ядро отряда перебропено из Москвы в апреле 1943 г. Отря.д должен действовать в Волковысском районе.

3. Группа т. СУКАЧЕВА Д.К. и СТРИЖАКА Т.Н. - членов Белостокского подпольного обкома КП(б)Б. При них 25-30 чел. партизан. Группа перебропена из Москвы в марте 1943 г.

4. Группа т. „ОВСЕЙЧИКА И.М. - долґна действовать в Скидельском районе. Перебропена из Москвы в августе 1943 года.

5. Группа т. ШУРМАНА И.С. - должна действовать в Снядовском районе. Перебропгена из Москвы в августе 1943 г. Сейчас группа выросла в отря,ц, в котором насчитывается 120 партизан, из них 7 коммунистов и 63 комсомольца.

6. Группа т. КУНДОВИЧА В.В. - должна действовать в Лапском районе. Перебропाена из Москвы в августе 1943 г. Сейчас группа выросла в отря,ц, в котором насчитывается 130 партизан.

7. Группа т. БАСТУНА П.Р. - должна действовать в Гродненском районе. Перебропена из Москвы в августе 1943 года.

8. Группа т. ТРОШЕВСКОГО А.Д. - должна действовать в Августовском районе. Шеребропена из Москвы в августе 1943 года.

8а. Группа т. СТОММА А.Л. - долљжна действовать в Чижевском районе. Перебропена из Москвы в августе 1943 года.

9. Бригада т. МАТОВОСЕЯНА - направляется из Минской области для действий в Бельском и Заблудовском районах. Вместе с этой бригадой следует группа т. Шломанова А.Г. для действий в Свислочьском районе.

10. Отря.Д т. ДЬЯКОВА - командир т. Дьяков Р. А., комиссар т. Ясюоеня Т. В., долґжен действовать в Кринковском и Соколковском районах. Численный состав 70 человек. Руководство отря.да перебропено из Москвы в августе 1943 года.

11. Группа т. КАРАБАНЬ Н.Л. - долљна действовать в Брянском районе. Перебропена из Москвы в сентябре 1943 года.

12. Группа т. СОКОЛЬЧИКА А.Ф. - должна действовать в Ломжинском районе. Перебропена из Москвы в сентябре 1943 года.

13. Группа т. ИСАЕНОК Я.И. - долљна действовать в Сопоцкинском районе. Шеребропена из Москвы в мае 1943 года.

14. Группа т. КАЗАКОВА М.А. - должна действовать в Кныппенском районе. Перебропгена из Москвы в мае 1943 года. ПРИМЕЧАНИЕ:

1. Численный состав каждой групшы 35-40 человек.

2. Группа т. Гордиенок Д.Н., предназначенная для работ в Гра- 
евском районе, задерзкалась в пути и находится в Полоцком районе Витебской области.

3. Из местного населения созданы отряды в Скидельском районе - 100 чел., в Гродненском районе - 35 чел., и в Волковысском районе - 135 чел. Последний отряд носит имя т. Котовского, командир отряда т. Кординов М.Г., комиссар т. Сарнычев А.Е.

4. Областное руководство состоит из секретаря подпольного обкома КП(б)Б т. Самутина (кличка „Емельянов”), нач. областного штаба партизанского движения генерал-майора т. Капуста $\Phi . \Phi$. (кличка „Костенко”) и редактора областной газеты т. Майхровича C.K.

В соединении т. Капуста насчитывается 800-900 партизан.

В группе т. Самутина находятся работники подпольного обкома ЛКСМБ.

5. В Белостокскую область передвигаются для боевых действий из Витебской области бригада т. Бубена и из Вилейской области бригада т. Талаквадзе.

14 октября 1943 г.

СЕКРЕТАРЬ БЕЛОСТОКСКОГО

ОБКОМА КП(б)Б (podpis) (ЭЛЬМАН)

Oryginal, maszynopis.

Źródło: NARB w Mińsku, zesp. 3630, spr. 1, t. 7, k. 51-52.

a Wielkie litery oryginału. 


\section{Dokument 8}

1943 listopad 20, Moskwa, - Wykaz brygad partyzanckich i podziemnych komitetów skierowanych do obwodu biatostockiego.

$$
\text { С II И С O K }
$$

\section{IIАРТИЗАНСКИХ БРИГА.Д И ІІОДІОЛЬНЫХ РАЙКОМОВ КП(б)Б БЕЛОСТОКСКОЙ ОБЈАСТИ. ${ }^{a}$}

\begin{tabular}{|c|c|c|c|c|}
\hline $\begin{array}{l}\text { Наименование } \\
\text { бригады }\end{array}$ & $\begin{array}{l}\text { Колич. } \\
\text { лодей }\end{array}$ & $\begin{array}{l}\text { Район } \\
\text { действия }\end{array}$ & $\begin{array}{l}\text { акие районы } \\
\text { беспечивает }\end{array}$ & $\begin{array}{c}\text { Фамилия секр. м.райкома } \\
\text { или райкома }\end{array}$ \\
\hline ІІокровский Г.Ф. & 1000 & Августовский & $\begin{array}{l}\text { Августовский } \\
\text { Домбровский } \\
\text { Сопоцкинский }\end{array}$ & $\begin{array}{cl}\text { секр. } & \text { МРК ТРАЦЕВСКИЙ } \\
\text { секр. } & \text { РК ИВАШКО } \\
” & \text { СЕМАШКО }\end{array}$ \\
\hline Войцеховский Н.К. & $183^{\mathrm{b}}$ & Белостокский & $\begin{array}{l}\text { Белостокский } \\
\text { Кнышинский }\end{array}$ & $\begin{array}{ll}” & \text { АНДРЕЕВ } \\
" & \text { КАЗАКОВ }\end{array}$ \\
\hline Балан & 600 & Цехановецкий & $\begin{array}{l}\text { Цехановецкий } \\
\text { Бельский } \\
\text { Брянский } \\
\text { ЈІапский }\end{array}$ & $\begin{array}{l}\text { секр. МРК Карабань } \\
\text { секр. межрайкома } \\
\text { КАРАБАНЬ } \\
\text { секр. РК КУНДОВИЧ }\end{array}$ \\
\hline Матовосьян & $738^{\mathrm{d}}$ & Волковысский & $\begin{array}{l}\text { Волковысский } \\
\text { Заблудовский } \\
\text { Свислочский }\end{array}$ & $\begin{array}{cc}\text { секр МКР СУКА ЧЕВ } \\
" ” \\
" & "\end{array}$ \\
\hline Беспоясов & 1000 & Г’раевский & & секр. МРК ТРАЦЕВСКИЙ \\
\hline Капуста $\Phi . \Phi$. & $1076^{\mathrm{f}}$ & Гродненский & $\begin{array}{l}\text { Гродненский } \\
\text { Скидельский }\end{array}$ & $\begin{array}{l}\text { секр. райкома БАСТУН П. } \\
\text { секр. РК ОВСЕЙЧИКБ }\end{array}$ \\
\hline Клевакин & 600 & ЈТомжинский & $\begin{array}{l}\text { Ломґжинский } \\
\text { Едвабновский }\end{array}$ & $\begin{array}{c}\text { секр. МРК СОКОЛЬЧИК } \\
"\end{array}$ \\
\hline Иванов & 500 & Замбровский & $\begin{array}{l}\text { Замбровский } \\
\text { Чижевский } \\
\text { Снядовский }\end{array}$ & $\begin{array}{cc}" & \text { СТОММА } \\
" & " \\
\text { секр. } & \text { РК ШУРМАН }\end{array}$ \\
\hline Бубен ${ }^{\mathrm{h}}$ & $250^{\mathrm{i}}$ & Кольновский & Кольновский & секр. МРК СОКОЛЬЧИК \\
\hline Дьяков & $180^{j}$ & Крынковский & $\begin{array}{l}\text { Крынковский } \\
\text { Соколковский }\end{array}$ & $\begin{array}{c}\text { секр. РК Ясюченя } \\
",\end{array}$ \\
\hline
\end{tabular}


Kopia, maszynopis.

Źródło: NARB w Mińsku, zesp. 3630, spr. 1, t. 7, k. 39-40.

a Wielkie litery i podkreślenia oryginału.

- Liczba wpisana odręcznie w miejsce skreślonej 150.

c Nazwisko sekretarza wpisane odręcznie.

d Liczba wpisana odręcznie w miejsce skreślonej 300.

e Nazwisko „Sukaczew” wpisane odręcznie w miejsce skreślonego „Baranow”.

${ }^{f}$ Licz ba wpisana odręcznie w miejsce skreślonej 1000.

g Nazwisko „Owsiejczyk” wpisane odręcznie.

h Nazwisko „Bubin” wpisane odręcznie w miejsce skreślonego „Leonow”.

i Liczba wpisana odręcznie w miejsce skreślonej 200.

j Liczba wpisana odręcznie w miejsce skreślonej 100.

\section{Dokument 9}

1943 listopad 28, Puszcza Lipiczańska, - Wyciag z protokotu posiedzenia Biatostockiego Podziemnego Komitetu Obwodowego $K P(b) B w$ sprawie dyslokacji $i$ nowych zadan brygad $i$ oddziatów zmuszonych do powrotu do puszczy.

В Ы П И С К $\mathrm{A}^{\mathrm{a}}$

из протокола Заседания Белостокского по,цпольного

Обкома КП(б)Б от 28 ноября 1943 года

С л уш а л и:

О месте дислокации и задачах брига,д им. Ал. Невского, им. Кастуся Калиновского и отря.дов: им.Жукова, им.Буденного, вынужденных в результате боев отойти в Липичанскую пущу.

Постановили:

В связи с тем, что проникновение и действие бригадами и больпाими отрядами на территории Белостокской области пока затруднено.

Обком КП(б)Б считает необходимым:

а) Послать в районы Белостокской области больпое количество боевых групп (60-70\% бригад и отрядов), пооставив перед каждой группой обязательную задачу закрепиться в указанном районе действия, на основе связи с населением. На этой основе организовать 
пропитание и сбор одежды, не догуска'ть беззаконной реквизиции, строго карать мародеров.

б) Обязать секретарей Райкомов КП(б)Б, ЛКСМБ, командиров и комиссаров бригад и отрядов, провести тцательный инструктаж не только командиров групп, но и всех бойцов, организовать действия групп таким образом, чтобы сохранить управление ими, не растерять их.

Комплектование групп провести по принципу супествуюших подразделений (взвод, отделение).

в) Посылаемым группам ставить не только боевые задачи, но и целый ряд других не менее важных задач.

А именно:

1. Рости и вооружаться.

2. Создавать боевые группы из местного населения.

3. Создавать антифапистские организации и резервные партизанские отряды, строго законсперированные.

4. Организовать внутреннюю оборону деревень.

5. Вести агитационную, пропагандистскую работу и распространять литературу.

6. Вести агентурную разведку и устанавливать пункты связи.

г) Обком КП(б)Б обраццет внимание Райкомов, командиров и комиссаров бригад и отря,дов на то, что в напих условиях необходимо усиленно развивать партизанское движение не только в форме Іодвиљжых, постоянно действуюгцих отрядов, но и в форме стационарно боевых е,циниц.

Партизаны этих боевых единиц живут дома и действуют в своем районе, являясь днем „мирными” хозяевами, а ночью диверсантами, боевиками, охотниками за фрицами, разведчиками и т.д.

д) Обком КП(б)Б рассматривает отход бригад и отрядов после боев как маневр, а нынепние места их дислокации, как временные. Действия посланных групп должны быть направлены к соз,даниғо условий для пере,цислокации всей боевой единицы бригады, отряда.

Передислокацию бригад и отрядов мелкими группами произвести в течении декабря 1943 года и января 1944 года. Обком КП(б)Б призывает партийных, комсомольских работников, командиров и комиссаров к смелому и репительному преодолению тру,дностей и борьбы, укреплению дисциплины, порядка и сплаченности в ря,дах партизан, к увеличению и росту напиих сил для беспоцадной борьбы с немецкими оккупантами. 
СЕКРЕТАРЬ БЕЛОСТОКСКОГО ПОДПОЛЬНОГО

ОБКОМА КП(б)Б (podpis) (САМУТИН)

Oryginal, maszynopis.

Źródło: NARB w Mińsku, zesp. 3630, spr. 1, t. 7, k. 67-68.

a Wielkie litery oryginału.

\section{Dokument 10}

1944 styczeń 6, Puszcza Lipiczańska, - Uchwata Białostockiego Komitetu Obwodowego $K P(b) B$ w sprawie karygodnego postępowania części dowódców wobec partyzantów.

П О С Т А Н О В Л Е Н И Е

Белостокского піодпольного Обкома КП(б)Б от 6 января 1944 года.

О фактах физического воздействия на партизан и грубых отнопाениях к ним со стороны командования отдельных отрядов.

Обкомом КП(б)Б установлено, что командование отдельных отря,дов применяет физические меры воздействия на партизан за соверпгенные нарупения дисциплины и недостойное поведение.

В отря.де им.Калинина (коман,дир отряда СТЕПАНОВ, комисcap ПЕТУХОВ, начальник пाтаба КИРИЧЕНКО) партизана тов. ИГОЩЕВА перед строем всего личного состава отрядда выпороли шомполами.

Нередкие случаи, когда командиры и комиссары отря,дов бригад вместо правильного командирского требования и убељдения партизан, становится на путь угроз расстрела, ругани и криков.

Подобные методы наказания и воздействия на партизан приводят не к укреплению дисциплины и порядка в отрядах, а к воспитанию у личного состава отря,дов боязни своих командиров и стремлению скрыть совершенные поступки. Применение методов физического воздействия, как правило имеет место там, где плюхо поставлена партийно-массовая, политическая, воспитательная работа среди партизан. 
Обком КП(б)Б П О С Т А Н О В Л Я Е Т:

1. Осудить меры физического воз.действия и запретить применять к партизанам у,дары пाомполом, как меру наказания. По.добные меры не согласуются с духом и принципами Советского воспитания людей.

В случае повторения подобных фактов, Обком КП(б)Б бу.дет строго взыскивать с партийных работников, коман,циров и политработников отря,цов и брига,д.

2. Предложить начальнику пाтаба партизанского движения Беэюстокской области тов. КАПУСТА из.дать приказ, запрещаююций коман,дованию отря,дов и бригад пользоваться физическими мерами наказания партизан и грубыми обращениями. Наказание партизан за нарупение дисциплины и другие недостойные поступки долґкны производиться по возможности, на основе дисциплинарного устава PККА.

3. Обязать секретарей $\mathrm{PK} \mathrm{КП(б)Б} \mathrm{весь} \mathrm{командный} \mathrm{и} \mathrm{полити-}$ ческий состав отря,дов и бригад усилить партийно-политическую, воспитательную работу среди партизан и партизанок. Представить Обкому КП(б)Б к 20.1.44 г. мероприятия политической работы среди личного состава отря,дов на январь и февраль 1944 го.да.

4. Секретарям Райкомов КП(б)Б личным участием оказать помоць политическому составу отря.дов и брига,Д. У лучппить политическое воспитание партизан и в каждом отдельном случае неправильного отнопения к партизанам, принимать немедленные меры.

5. Райкому КП(б)Б ознакомить с данным репгением всех коман,диров, комиссаров отря,дов и бригад и обсудить на закрытых партийно-комсомольских собраниях.

СЕКРЕТАРЬ БЕЛОСТОКСКОГО ПОДПОЛЬНОГО ОБКОМА КП(б)Б (podpis) (САМУТИН)

Oryginał, maszynopis.

Źródło: NARB w Mińsku, zesp. 3630, spr. 1, t. 7, k. 79.

a Wielkie litery oryginału. 


\title{
Dokument 11
}

1944 marzec 1, Moskwa, - Raport Wydziatu Operacyjnego BSzRP z akcji przerzucania do zachodnich obwodów BSRR zgrupowań partyzanckich i grup organizatorskich.

Әкз. № a

\section{НАЧАЛЬНИКУ БЕЛОРУССКОГО ШТАБА ПАРТИЗАНСКОГО ДВИЖЕНИЯ}

тов. КАЛИНИНУ П.З.

\begin{abstract}
ДОКЛАДНАЯ ЗАПИСКА
о ходе выполнения операции по пере,дислокации партизанских сое,цинений и переброске организаторских групп в запа,дные области Б С С Р.
\end{abstract}

В соответствие с постановлением Бюро ШК КП(б)Б и Вашими указаниями, планом мероприятий по дальнейшему развитию партизанского движкения в западных областях Белоруссии предусмотрено:

1) В течение летнего периода 1943 года:

а) пере,цислоцировать из восточных областей Белоруссии в запа,дные области 5 партизанских бригад и 23 от,дельных отря,да;

б) перебросить из Москвы самолетами 16 организаторских групп с за,цачами: на базе действуюцих брига,ц в восточных областях сформировать 1 партизанскую бригаду и 15 от,дельных отря,дов, численностью 50-70 челювек каждый, с дальнейшей передислюкацией их в западные области;

в) перебросить из Москвы 9 челгвек радистов с рациями дляя брига,д и отрядов, намеченных к передислоцированию;

г) забросить вооружение, боеприпасы и другие грузы для бригад и отря,дов как для пере,цислоцируюгцихся, так и для вновь сформированных, облцим количеством 48 самолетовылетами.

2) В течение осенне-зимнего периода:

а) передислоцировать из восточных областей Белоруссии в западные области 18 партизанских брига,д;

б) перебросить самолетами 14 челювек радистов с рациями для брига,ц, намеченных к передислоцированию; 
в) забросить вооружение и боеприпасы и другие грузы для брига,ц, облцим количеством 33 самолетовылетами.

По состоянию на 1.3.44 г. в соответствие с летным планом передислокации проведены следующие мероприятия:

1) Переброшено из Москвы 15 организаторских групп и редакция Белостокской областной газеты;

2) из личного состава, выделенного из Слуцкого соединения сформирована о.дна партизанская бригада численностью 747 человек, по,ц командованием генерал-майора т. Капуста. Бригада на отчетное число реорганизована в три брига,ды, которые дислоцируются в Јепечанской и Ружанской пущах, Барановичской и Брестской областей.

3) все организаторские группы развернуты в отдельно действуюпие отряды и находятся в пути в свои районы действий и на отчетное число достигли районов Брестской и Барановичской областей:

отряды: Бастуна, Трацевского, Овсейчика временно дислоцируются в Щучинском, Желудокском районах, Барановичской области;

отря,ды: Шурмана, Карабань, Сокольчика, Стома, Дьякова временно дислоцируются в Ружанском, Коссовском и Березовском районах Брестской области. С получением боевых грузов все отрядыы будут продвигаться в свои районы боевых действий;

организаторские группы: Јеоновича, Шунько, Синявского достигли своих районов и приступили к работе, согласно задания ПК КП(б)Б и штаба.

4) из бригад Титкова, Воронянского, Дубровского, Лобанок, Мельникова вы,делено 7 партизанских отрядов, общей численностью 840 человек.

К 10.10.43 г. все отряды передислоцированы в Вилейскую область:

а) отря,д, выделенный из бригады Титкова, численностью 210 человек, по.д командованием т. Клеменского, передислоцирован в Свирский район;

б) отря,д, выделенный из бригады Воронянского, численностью 80 человек, под командованием т. Короткого, передислоцирован в Ошмянский район;

в) второй отря.д, выделенный из бригады Воронянского, численностью 100 человек, по,д командованием т. Карпенко, передислоцирован в Сморгонский район; 
г) отря.Д, выделенный из бригады Дубровского, численностью 100 человек, под командованием т. Акулова, передислоцирован в ІІІарковцизненский район;

д) отряд, выделенный из бригады Јобанок, численностью 150 человек под командованием т. Мисунова, передислоцирован в Мојодечненеский район;

е) отряд, выделенный из бригады Мельникова, численностью 100 челювек, под командованием т. Клименок, передислоцирован в Браславский район;

ж) второй отря,д, выделенный из бригады Мельникова, численностью 100 человек, по,д командованием т. Гавриленко, передислоцирован в Миорский район.

5) Бригада им. Флегонтова, численностью 403 челювека, передислоцирована в Дивинский район Брестской области, совместно с бригадой выпла организаторская группа во главе с уполномоченным ІІК и пाтаба по Малорытскому району т. Кучера.

Отря,д Яроцкого, численностью 228 человек, передислоцирован из Могилевской области в Березовский район, Брестской области.

Бригада им. Чапаева (командир Матевосян), численностью 438 человек, передислоцирована из Минской области в район Ружанской пуши, Брестской области. Совместно с бригадой движется организаторская группа т. Шламанова.

Отря,ц Бубена, численностью 100 челювек, передислоцирован из Витебской области в Новогрудский район, Барановичской области, на отчетное число на базе отряда сформирована 1-я Барановичская бригада, числгенностью 367 человек.

Белорусским пाтабом партизанского движения забропген груз бригадам и отрядам, обцим количеством 10 самолетовылетов.

Согласно пллану произведено самолетовылетов: с грузом 16, с люодьми 16 , итого - 32 .

ІІо состоянию на 1.3.44 г., в соответствие с осенне-зимним плјаном передислокации проведены следуюгце мероприятия:

1) бригада им. Языковича (командир Велигин), сформированная из личного состава, выделенного из бригады Жигаря, численностью 500 челювек, передислоцирована из ІІолесской области в Березовский район Брестской области, с дальнейпей задачей выйти для действия в Домачевский район, этой же области;

2) бригада им. Гуляева (командир Яковенко), численностью 
371 человек, передислоцирована из минской области в Березовский район Брестской области, с дальнейшей за,дачей выйти для „цействий в Клещельский район;

3) бригада Жунина, сформированная из личного состава, выделенного из брига,д Кирпича, Жунина, численностью 948 человек, передислоцирована из Могилевской области в Брестскую область и на отчетное число находится в пути в свой район; достигла м. Телгханы, Пинской области;

4) 208 піолк (командир Беспоясов), численностью 1200 человек, находится в пути в свой район и на отчетное число достиг м. Телеханы, Пинской области;

5) отряд Михолапа, численностью 225 человек, передислоцирован из Могилевской области по решению Могилевского обкома КП(б)Б, в Клецкий район, Барановичской области;

6) бригада им.Пономаренко (коман.цир Иванов) численностью 500 человек, сформированная в результате разделения 2-й Минской партизанский брига,ды, передислоцирована из Минской области в Пинскую область с дальнейшей за,цачей выйти в Замбровский район Белостокской области;

7) бригада Дрожникова Могилевской области, нахо,дится в пути в Слонимский район, Барановичской области, и на отчетное число проследовала м. Марьина Горка, Минской области.

По состоянию на 1.3.44 года ІІлан передислокации партизанских бригад и отрядов из восточных областей в западные области Белоруссии выполнен:

а) к передислокации и выброске намечалось

18 партизанских брига,д

10 партизанских отря,дов

15 организаторских групп (из Москвы)

формирование одной партизанской бригады;

б) передислоцировано и выброшено

9 партизанских брига,

10 партизанских отрядов

15 организаторских групп (из Москвы);

в) не выполено:

из-за сложивпгейся обстановки были оставлены в районах прежней дислокации бригады Морозова, Захарова, Јеонова, Шлапакова, Комлева, Покровского, Балана, Дербана, Корешкова, полк Са,цчикова, отряд Мармулева; 
г) из-за отсутствия достаточного количества авиатрансіортных средств не заброшено боевых грузов для бригад и отрядов общим количеством 33 самолетовылета.

Несмотря на проведенные мероприятия, бригады и отряды, направляноциеся в Белостокскую область, в свои районы не выпли и на отчетное число нахо,дятся в Барановичской области и северной части Брестской области.

О наличии партизанских отря,дов на территории непосредственно Белостокской области БШПД данными не располагает. Боевые действия проводятся периодически, выходом на коммуникации от,дельных диверсионных групп.

В целях дальнейлего развития партизанского двиљкения и активизации боевых действий в запа,дных областях Белоруссии и, в частности, Белостокской области, считаем необходимым провести сле,дующие мероприятия:

1. Необходимо в ближайшее время бригадам и отрядам, нахо,дяІцимся в пути и ожи,цаюоцим груза, забросить вооружение, боеприпасы и взрывматериалы, облцим количеством 10 самолетовылетов, используя для этих целей работағщие на партизан Белоруссии самолеты ЛИ-2 и СИ-47. С получением грузов дать категорические указания о выходе в свои районы действий;

2. Не ожидая заброски грузов, дать указание бригадам: Балана, Дербана, Корешкова, отря,ду Мармулева о выступлении в районы новой дислокации, намеченные планом;

3. Из соединения Мовчанского выделить 5-6 хоропо вооруженных отряддов, численностью 200-250 человек каж,дый с за,дачами передислокации в западные районы Белоруссии;

4. Для успепного про,движения бригад и отрядов в назначенные районы действий Белостокской области провести следующие организационно-тактические мероприятия:

а) из бригад и отрядов, находящихся непосредственно на границе Белостокской области, соз,дать боевые отря,цы численностью 50-100 человек, включив в состав этих отря,дов группы уполномоченных по районам, с имеюгцимися у них ра,циостанциями;

б) сформированным отря,дам поставить конкретные боевые за,дачи по одновременному выступлению в назначенные районы действий с разных направлений, с целью деезориентировки противника и недопущения сосредоточения его сил на каком-либо одном направлении. В случае слољжной обстановки при переходе через ж.д., поставить 
местным брига,дам задачи по обеспечению и оказанию помоци при про,движении отря,дов;

в) с выхо,дом отря,дов в свои районы развернуть работу піо освоению районов и по,цготовке баз, для прибываюоцих брига,ц впосле,цствии;

г) развернуть боевые действия на шоссейных и железных дорогах Іо ,цезорганизации тыла противника.

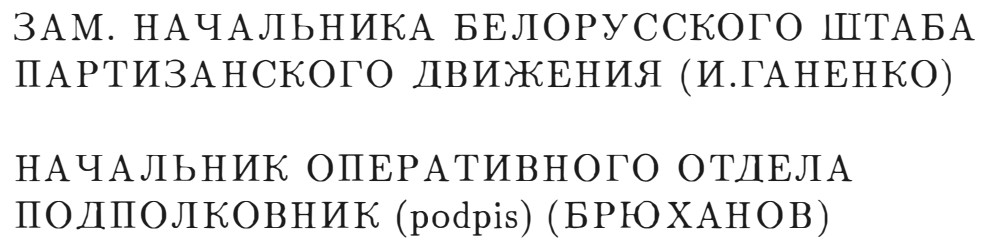

1.3.44.

Исп. по,цполковник Шутов.

2 экз. л1з.

Dokument poprzedza (k.1) następu jąca adnotacja: „T. Briuchanow. Proszę materiał sprawdzić i zaadresować raport na imię t. Ponomarenki. 9.4.44., Ganienko” oraz „Tow. Szutow, Skontaktujcie się ze mną. 9.4.44, Ponomarenko".

Oryginał, maszynopis.

Źródło: NARB w Mińsku, zesp. 3500, spr. 2, t. 1026, k. 2-6.

a Brak numeru.

b Wielkie litery i podkreślenia oryginału. 


\section{Dokument 12}

1944 marzec 25, Raport wydziatu operacyjnego BSzRP o stanie wykonania zadań zwiazanych z przerzucaniem radzieckich formacji partyzanckich do obwodów biatostockiego i brzeskiego.

\section{ЗАМЕСТИТЕЈЮ НА ЧАЛЬНИКА БЕЈІОРУССКОГО ШТАБА ПАРТИЗАНСКОГО ДВИЖЕНИЯа}

\section{Докла,дная записка}

В соответствии с постановлением бюро ЩК КП(б)Б и Вашими указаниями, партизанские бригады и отря,ды, намеченные к передислокации, из своих районов дислокации выстугили и к 20.3.44 достигли:

Белюстокское соединение - брига,да имени Ал-дра Невского (к-р Ещенко), отряд „Боевой” (к-р Гриценевич), отряд им.Калинина (к-р Степанов), отряд им. Жукова (Трацевский) - района Јепечанской пущи, Барановичской области;

Брига,ды: им. Чапаева (к-р Матавасьян), им. Кастуся Калиновского (к-р Войцеховский), „Во имя Родины” (к-р Янковский), отряды: им.Пономаренко (к-р Нестеров), им. Буденного (Шурман) - района Ружанской пущи, Брестской области.

208 полк Беспоясова - района Телеханы, Цинской области.

Отряды: им. Богдана Хмельницкого (Карабань), им. Дзержинского (Сокольчик), отряд Дьякова - района оз. Споровское, Брестской области.

Брига,ды, направляюшиеся в Брестскую область, достигли: им. Гуляева - района оз.Споровское, бригада Жунина - м. Великая Гать (12 км. с-з Телеханы).

Таким образом, перечисленные брига,ды и отряды своих районов не достигли, неоднократные попытки бригад продвинуться в свои районы, успеха не имели, из-за слюживпейся обстановки по маршруту движения бригад (сосредоточенние противником превосходяяпих сил на пути движения бригад и болыпое количество гарнизонов).

Изучение обстановки и опыта боевых действий в районах Брестской и Белостокской областей показывает:

a) По линии: Гродненская пуща, ст. Мосты, р. Зельвянка, м. Менжирец, Порозово, ПШерешево и далее на юго-запад проходит, так называемая, граница Восточной Пруссии, которая охран.яется 
немецкими пограничными кор,донами, для перехода границы существуют специальные пропуска;

б) В районах пограничной полосы имеется большое количество гарнизонов противника;

в) Шоссейные и зк.ц. коммуникации противника усиленно охраняются;

г) Местное население за малейшее оказание помоци партизанам - или не своевременное сообшение о появлении партизан, полдергается суровым репрессиям.

В такой обстановке попытки выхода в свои районы партизанских брига,д в полном составе, особенно в условиях отсутствия боепринасов, сопрязены с больпими поотерями.

На запрос штаба о возможностях продвизкения брига,ды им. Гуляева в Клещельский район, т. Сикорский 18.3.44 сооблцил, что: „Брига,ду сейчас направлять в Клецельский районе нецелесообразно, обстановка там сложная и брига,да будет разбита, пока будем направлять мелкие группы".

В районах Гродненском, Скидельском, Волковыском, Свислочском, Белостокской области, боевые действия проводятся диверсионными группами, вы,деленными из брига,ц.

Исходя из этого, следовало бы командованию партизанских брига,Д, которые долґкны выйти в районы Брестской и Белостокской областей, дать указания примерного содержкания:

Для освоения новых районов Вашей дислокации в ближайшие 10-15 дней сформируйте 2-4 группы по 25-30 человек каж,дая с сильным вооружением, полным боезапасом и направьте их как разведыватедльне, в случае благоприятной обстановки, группам осесть в за,цанных районах и действовать до подхо,ца основных Ваших сил. Связь с группами установите посыльными. Группы дислоцируйте поэшелонно с постепенным у.далением базирования.

Боеприпасы Вам выбросим в первые летние ночи.

НА ЧАЛЬНИК ОПЕРАКТИВНОГО ОТДЕЛА БШПД ПОДПОЛКОВНИК (podpis) (БРЮХАНОВ)

СТ. ПОМОЩНИК НА ЧАЛЬНИКА ОПЕРОТДЕЛА ПОДПОЛКОВНИК (podpis) (ШУТОВ)

225" в марта 1944 г.

eII- 2 . 
Na lewym marginesie u góry ukosem adnotacja: „tow. Szutow (podkreślone) Chronić w aktach, 3.IV.44, Briuchanow"

Oryginał, maszynopis.

Źródło: NARB w Mińsku, zesp. 3500, spr. 2, t. 1026, k. 26-27.

a Wielkie litery i podkreślenie oryginału.

b Dzień wpisany odręcznie.

\section{Dokument 13}

1944 kwiecien 18, - Wyciag z protokotu nr 211 Biura KC KP(b)B przedstawiajacy decyzje $w$ sprawie przygotowan do przejmowania wtadzy $w$ obwodzie białostockim ${ }^{1}$.

9. $\underline{\text { СЛУШАЛИ: }}{ }^{\mathrm{a}}$ Вопросы Белостокского Обкома КП(б) Белоруссии.

ПОСТАНОВИЛИ:

1. Принять предложение Белостокского Обкома КП(б)Б о включении группы работников Обкома КП(б)Б во главе с секретарем обкома т. Эльманом в оперативную группу Белорусского штаба партизанского двиљкения на 1-м Белорусском фронте.

Поручить Начальнику Штаба Белюрусского партизанского движения т. Калинину, начальнику оперативной группы штаба на 1-м Белорусском фронте и т. Эльману организовать связь с подпольными партийными организациями и партизанскими отряддами, действуюцими на территории Белостокской области, и оказать им помоць в обеспечении вооружением, боеприпасами и организовать засылку печатных из,даний в районы Белостокской области.

2. Поручит т. Кудряеву для повседневной связи с Белорусским штабом партизанского двизкения прикомендировать к Оперативному от,делу штаба одного из работников обкома КП(б)Б.

3. Поручить Секретарю Белостокского Обкома КП(б)Б т. Кудряеву развернуть работу по подготовке партийного и советского аппарата области к возобновлению своей деятельность на территории области в момент ее освобож,дени.я от немецких оккупантов дляя чего имеюоцихся в распоряжении обкома партийных и советских работников уже сейчас распределить по соответствуюцим отрасл.ям 
партийной, госу,дарственной и хозяйственной работы. Определить основной состав руководящих партийных и советских работников для каж,дого района области.

4. Обязать Белостокский Обком КП(б)Б создать при обкоме резерв партийных и советских работников для комплектования аппарата областных и районных партийных и советских органов в количестве не менее 100 чел. С этой целью вызвать из восточных областей СССР работников, ранее работавших в Белостокской области.

Поручить т. Кудряеву совместно с Отделом ка,дров ПК КП(б)Б и Белорусским пाтабом партизанского двизкения внести пре,дложения об отзыве из тыла противника в распоряљкение Белостокского Обкома КП(б)Б 25 работников.

5. Предрепить вопрос об откомендировании в распоряжение Белостокского Обкома КП(б)БЮ, по мере освобождения районов Белостокской области, следующих работников Белостокской области, ныне работающих в других областях БССР:
1. Сороколестова Н.В.
9. Кец $\Phi$. В.

2. Чарина П.Т.

10. Науменко Н.Н.

3. Токарева П.Ф.

11. Дубовко Т.А.

4. Солдатенко М.Д.

12. Григорьева В.JI.

5. Медвецкую Д.Г.

13. Дмитреву А.М.

6. Денисюок В.И.

14. Крейнина JI.C.

7. Кунцевич Д.И.

15. Яацкович Г.Д.

8. Мельникову П.JI.

16. Ковалева А.Т.

17. Лисову Г.П.

24. Ильинок М.К.

18. Фрейндорф Б.А.

25. Романову А.Н.

19. Хващенко Т.Э.

26. Позднякова И.Б.

20. Дапкевй Г.С.

27. Сироткину П.

21. Перехо,д А.Е.

28. IIпак М.

22. Киселеву Т.С.

23. Макренко И.Т.

29. Шах Н.П.

30. Кислик

6. Поручить обкому КП(б)Б по,дготовить соображения по укомплектованию работниками госу,дарственных учреждений и предприятий в районах Белостокской области.

7. Местонахождения Белостокского Обкома КП(б)Б определить г. Ново-Белица.

Обязать Управление делгами ШК КП(б)Б предоставить обкому КП(б)Б соответствующее помещение для работы и для жжилья работников. 
Вы,делить в распоряжение Белостокского обкома КП(б)Б о.дну легковую автомашину.

$\Gamma \Pi-3$

СЕКРЕТАРЬ ЦК КП(б)БЕЛОРУССИИ (podpis) (П.КАЛИНИН)

Oryginał, maszynopis.

Źródło: NARB w Mińsku, zesp. 4, spr. 61, t. 51, k. 15-16.

1 Decyzje przy jęto tzw. obiegiem.

a Duże litery i podkreślenia oryginału.

\section{Dokument 14}

1944 kwiecień (brak dnia), Moskwa, - Projekt uchwaty KC KP(b)B w sprawie pomocy biatostockiej podziemnej obwodowej organizacji partyjnej.

ПОСТАНОВЛЕНИЕ

Проект

ШЕНТРАЛЬНОГО КОМИТЕТА КП(б)БЕЈОРУССИИ от " " апреля 1944 г.

О мерах помощи Белостокской областной Іодпольной парторганизащии

ЦК КП(б)Белоруссии считает, что важнейшей за,дачей Белостокской областной по,дпольной парторганизации на блиљкайший перио.д является усиление партизанского двиљкения во всех районах области и нанесение ударов немецко-фашистским захватчикам, широкий охват политическим влиянием населения области и, как ближайшая конкретная за,дача, определяғощая успех партизанского движкения области - овладение Гродненскими лесами области.

В целях выполнения этих задач, ШК КП(б)Белоруссии - ПОСТАНОВЛЯЕТ: 
1. Утвердить представленный Белорусским пітабом партизанского движения план оперативно-организационных мероприятий пІо дальнейшему развитию партизанского движения и активизации борьбы партизан с фашистскими захватчиками в Белостокской области.

2. Отмечая, что в Белостокской области действуют только 7 подпольных райкомов КП(б)Б (Волковысский, Свислочский, Скидельский, Гродненский, Сопоцкинский, Лапский и Снядовский и 2 межрайкома - Августовский с охватом Августовского и Граевского районов и Чижевский - с охватом Чижевского и Замбровского районов), - обязать Белостокский подпоольный обком КП(б)Б организовать райкомы КП(б)Б в Заблудовском, Домбровском, Белостокском, Кныпинском, Крынковском и Соколковском районах и в месячный срок представить состав райкомов на утверждение ЦК КП(б)Б.

Обязать секретарей межрайкомов КП(б)Б: Ломжинского - т. Сокольчика и Брянского - т. Карабань в кратчайпиий срок выйти в районы их действия и установить связь с подіольным обкомом КП(б)Б .

3. Обязать ЦК ЛКСМБ организовать подпольные комсомольские организации в тех районах области, где они еше не созданы.

4. Учитывая малючисленность Белостокской областной парторганизации и необходимость болыпего насыцения коммунистами партизанских отрядов Белостокской области, обязать Минский подпольный обком КП(б)Б увеличить партийную прослойку в отрядах и бригадах, направляемых из Минской облгасти в Белюстокскую область.

5. Считая одной из важнейших задач подпольной парторганизации развертывание политической работы среди населения, о.добрить инициативу Белостокского подпольного обкома по созданию областного и пляти районных антифапистских комитетов, и предложить обкому КП(б)Б создать антифапистские комитеты во всех районах области, поставив перед ними задачи создания скрытых партизанских резервов, развертывания диверсионной и разведывательной работы, особенно в городах и гарнизонах противника, и противодействия враждебной деятельности польских националистических организаций.

6. Предложить отделу пропаганды и агитации ЦК КП(б)Б в течение апреля-мая выделить, а Белорусскому пाтабу партизанского 
движения забросить в область: 2 печатных мапины, типографскую краску, пाрифты, 600 килограмм бумаги, 50 библиотечек массовой политической литературы.

Oryginał, maszynopis.

Źródło: NARB w Mińsku, zesp. 3630, spr. 1, t. 7, k. 37-38.

a Wielkie litery i podkreślenie oryginału.

\section{Dokument 15}

1944 kwiecień (brak dnia), Moskwa, - Plan dziatań operacyjno-organizatorskich zabezpieczajacych rozwój radzieckiego ruchu partyzanckiego w obwodzie biatostockim.

УТВЕРЖДЕН

НА БЮРО ШК КП(б)БЕЛОРУССИИ

экз.№ ....

" " апреля 1944 года

\section{ПI Л A H}

оперативно-организационных мероприятий по дальнейпему развитию партизанского движения и активизации борьбы партизан Белостокской области с фашистскими захватчиками.

I. Для проведения боевой операции по разгрому враждебных гарнизонов в районе Гродненских лесов и преврацению этих лесов в опорный пункт для партизанских соединений, в Гродненский район передислоцировать следуюцие партизанские соединения:

бригаду Корешкова - в составе 600 человек;

бригаду Кузнецова - в составе 800 челювек;

бригаду Балана — в составе 1000 человек;

бригаду Базылевича - в составе 1000 человек;

бригаду Мармулева - в составе 600 человек;

бригаду Покровского - в составе 1500 человек.

Перечисленным партизанским соединениям через 15 дней после получения директивы пाтаба выступить кратчайшим марпірутом 
в район Гродненских лесов, где по прибытию, под общим руководством Белостокского обкома КП(б)Б, совместно с местными партизанскими бригадами, разгромить немецкие гарнизоны и прочно овладеть Гродненскими лесами.

II. В обеспечение намечаемой операции, провести следуюгее:

1. Направить в партизанские соединения Минской восточной зоны представителя БШП.Д с задачами:

а) довести настояшую директиву до сведения и руководства командиров, комиссаров партизанских соединений, предназначенных к передислокации;

б) для координации действий парттизанских соединений на марше создать оперативную группу в составе: командир оперативной группы - тов. Балан (по совместительству с основной должностью командира партизанской бригады), представитель БШДП и 2 помоцника коман,дира оперативной группы - первый - ІІо оперативной части, второй - по разведке (назначаются на месте);

в) совместно с командованием оперативной группы подготовить партизанские соединения к передислокации и разработать необходимые мероприятия дляя осуществления марша;

г) принимать и распределять, совместно с командованием оперативной группы, боеприпасы и вооружение, выбрасываемые БШП.Д партизанским соединениям, намеченных к передислокации;

д) информировать БШП.Д о ходе подготовки и проведения марша партизанских соединений в районе Гродненских лесов;

е) совместно с руководством подіольного обкома КП(б)Б Белостокской области, участвовать в разработке операции по разгрому вражеских гафнизонов района гродненских лесов и овладению этими лесами.

2. Выбросить радистов с радиостанциями для организации радиосвязи между оперативной группой и партизанскими соединениями на марше.

3. Доставить всем партизанским соединениям, намеченным для передислокации, боеприпасы и вооружение из расчета не менее двух тонн на каждое соединение (по прилагаем. расчету)

4. Обеспечить командование оперативной группы необходимыми разведданными для совершения успешного перехода партизанских бригад в район Гродненских лесов и предотвращения столкновений партизанских соединений с крупными силами противника.

III. Партизанская бригада тов. Покровского в район гродненских 
лесов передвигается самостоятельно. Задачу на марш этой бригаде довести по ра,цио.

IV. Для обеспечения боевых действий суцествующцх партизанских бригад и отря,дов Белостокской области, забросить в течение апреля месяца 1944 года боевых грузов обццим количеством 9 тонн, в том числе:

Тол прессованный ........... - 2,5 тонны

Патронов винтовочных русских ... - 150 тыс. пІт. - 3,3 тонны

Винтовки (карабины) ........... - 100 пाтук - 0,4 тонны

Автоматы................. 60 пाтук $\quad$ - 0,8 тонны

Патроны ТТ............... - 160 тыс. піт. - 0,8 тонны

Ручные пулеметы.............. - 20 піт. $\quad$ - 0,3 тонны

Минометы ротные (с комплектами) - 6 іпт. _ $\quad$ - 4 тонны

П Т Р с боекоміл ............. 4 піт. $\frac{-0,4 \text { тонны }}{8,0 \text { тонн }}$

гранаты Т-1, ружейные гранаты, упроценные взрыватели, капсюля мины МЗЛ, медикаменты (2 аптечки), 20 комплектов обмундирования для комсостава, мыло туалетного - 20 кгр., табак - 20 кгр. облцим весом о,цна тонна.

V. B целях сохранения партизанской агентуры, командирам и комиссарам партизанских соединений и подраз,делений не допускать, при прохождении районов, каких-либо репрессий без ведома местных партизанских отря,дов по отнопению лиц, состояццих на службе у немцев.

VI. Обратить внимание коман,диров, комиссаров и партийных организаций партизанских соединений, что успех операции в районе гродненских лесов во многом будет завцсеть от сохранения в строгой тайне целей ц задач пере,цвижения партизанских сое,цинений, от правцлььных взалмоотнопений на марше с местным населением и местными партизанскцми отря,дами ı бригадами. Поэтому необходимо среди личного состава партизанских соединений, намеченных к передислокации, провести серьезную раз'яснительную работу о соблю,дении железной волнской дисциплины на марше, сохранении военной тайны, правцльных взалмоотнопений с местными партизанскими отря,дами, бригадами и местным населением, а такље о строгой персональной ответственности коман,диров, комиссаров сое,цинений и подраз,целений и всех партизан за поступки, порочацце высокое звание советского партизана. 


\section{НАЧАЛЬНИК БЕЛОРУССКОГО ШТАБА ПАРТИЗАНСКОГО ДВИЗЖЕНИЯ (П.КАЛИНИН) \\ НАЧАЛЬНИК ОПЕРАТИВНОГО ОТДЕЛА БШП.Д - ПО.ДПОЛКОВНИК (БРЮХАНОВ)}

B е р н о:

Cr. пом. начальника Оперативного отдела БШП.Д - подцполковник (podpis) (Шутов)

Kopia, potwierdzona.

Źródło: NARB w Mińsku, zesp. 3630, spr. 1, t. 7, k. 69-71.

a Wielkie litery i podkreślenia oryginału.

b Wymienionego dokumentu w teczce brak.

\section{Dokument 16}

1944 maj 4, - Uchwata Biatostockiego Podziemnego Komitetu Obwodowego $K P(b) B w$ sprawie sytuacji $w$ oddziale partyzanckim im. Żukowa.

Сов.секретно Экз.

\section{Постановление}

Белостокского подпольного обкома КП(б)Б от 4 мая 1944 года

О полюжении в отряде им. Жукова

Обком КП(б)Б отмечает, что в отряде им. Жукова в ночь на 2-ое мая имел место, из ряда вон выходящий, случай дебоша, повлекпий за собой жертвы -3 чел. 1 убито и 2 ранено.

Инициатором мяного дебоша и раз,дула является командир отряда СИДОРЕНКОа, неоднократно наказываемый за хулиганское поведение, пьянку, стрельбу по партизанам. Своим поведением СИДОРЕНКО подрывал ,цисциплину, разлагал отря.д. Прошлое СИДОРЕНКО ,дает об'ьяснение его поведения. СИ.ДОРЕНКО в 1942 году пошел на службу к немцам, окончил у них в г. Минске 3 -х 
месячные офицерские курсы и до декабря 1942 года служил оккупантам начальником „Самаховы” с. Дзержинска. В отряде подрабатывал отдельных партизан и командиров, пытаясь противопоставить их партийному руководству.

В ночь на 3-е мая СИДОРЕНКО преднамеренно напоил группу партизан и сознательно организовал вооруженное напа,дение на дом, где нахо,цился секретарь межрайкома тов. Трацевский. Шель СИДОРЕНКО также высказано партизанам - убить Трацевского и группу москвичей ц увести отряд не в район действия, а за линию фронта.

Секретарь Межрайкома тов. Трацевский ${ }^{\mathrm{b}}$ проявил политическую близорукость и не только во время не вскрыл лицца СИДОРЕНКО, не разоблачил его, а наоборот, сволм поведением, недостойным партийного руково,дителя, соз,давал благона,дежную атмосферу для грязных дел СИДОРЕНКО.

Вопреки предупреждениям Обкома, ТРАІЕВСКИЙ продолжал пьянствовать, угрожать расстрелами партизанам, запугивал их выстрелами над ухом и другими угрозами. Чаще всего это делалось в нетрезвом состоянии. В этом принимал также участие комиссар отря,да т. РОГОЗИНСКИЙ. И в день 1-го мая ТРАІЕВСКИЙ позволили себе, в присутствии партизан, стрелять по СИДОРЕНКО и был обезоружен партизанами.

Шри всем этом политико-воспитательная и боевая работа отря,да находилась на нцзком уровне.

Исходя из выне изложенного, Белостокский по,дпольный обком $\operatorname{KII}($ б) $\mathrm{B}$

Постанавляет:

1. Шре,цложить тов. ПЕТРИЧЕНКО тщательно расследовать обстоятельства ,цела и закончить произво,цство в 3-х дневный срок.

Принять к сведениғ сообшение сле,цственных органов о том, что СИДОРЕНКО и ком. роты СКОРИК, убивший бывшего коман,цира отря,да им. Дзержинского, арестованы.

Т. Капуста, по окончанию следствия, главных виновников политического бандитизма - СИДОРЕНКО и СКОРИКА, подвергнуть скорейшему наказанию по законам военного времени.

2. Осудить поведение тов. ТРАШЕВСКОГО, проявившего политическую близорукость, продолжавшего пьянствовать и запугивать партизан стрельбой, неумевшего поднять политико-воспитательную работы и боевую деятельность отряда, своим, недостойным партийного руково,цителя пове,цением, давшего пово, к бандитскому 
разгулу - вынести тов. ТРАЦЕВСКОМУ строгий выговор с предупреж,дением. О чем поставить в известность ЦК КП(б)Белоруссии.

3. Комиссару отряда тов. РОГОЗИНСКОМУ объ.явить выговор за недостойное пове,дение и холатное отнопение к исполнению своих обязанностей.

4. Считать целесообразным отстранение от должности командира роты НОСЕВИЧА и перевод его, а также группы других партизан из отряда им. Жукова. В отря,д им. Жукова перебросить из других отрядов группу командиров и партизан.

5. Намеченный на 5-го мая выход отряда в район действия, отложить до 25 мая.

6. Предлоожить парторганизации отряда им. Жукова обсудить вопрос о состоянии политико-воспитательной и боевой работы в отряде, об оздоровлении отря,да и о пове,дении от,дельных коммунистов и комсомолььцев.

Обязать тов. ТРАЦЕВСКОГО, совместно с вновь назначенными коман,дирами и политработниками, в период до ухода в район действия, провести больпую разъяснительную политико-воспитательную работу, направленную на оздоровление политико-морального состояния и подцнятия боевого духа отряда.

Настоящее постановление обсудить на закрытых партийных собраниях брига,ц и отрядов.

Секретарь Белостокского Подпольного Обкома КП(б)Б (podpis) (САМУТИН)

Отп. в 12 экз.

Oryginał, maszynopis.

Źródło: NARB w Mińsku, zesp. 3630, spr. 1, t. 6, k. 33-34.

a Duże litery oryginału.

b Podkreślenie oryginału. 